ORIGINAL PAPER

\title{
Clinicopathological CHARACTERistics OF BREAST SEBACEOUS ADENOCARCINOMA
}

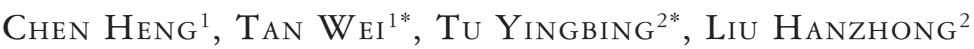

${ }^{1}$ Wuhan University of Science and Technology Hospital, Wuhan, China

${ }^{2}$ Xiaogan City Centre Hospital, Xiaogan, China

*Both authors contributed equally to this manuscript.

Two middle-aged females presented with a mass located in the lateral quadrant of the breast. Both patients received modified radical surgery for breast cancer, radiotherapy, and chemotherapy and have been living without evidence of disease for more than one year. Under the microscope, we observed that the tumour cells were organised in a solid nest-like or leafy distribution and comprised sebaceous gland cells and oval or fusiform cells. The differences between the two cases are as follows: First, the mass in the first case had a mixed echo pattern on ultrasound, whereas that in the second case had a hypoechoic pattern. Pathology revealed the presence of irregular cysts in the first case, which was consistent with the ultrasound features, and microscopy revealed the presence of necrosis in the tumour. Second, the first case was strongly positive for HER-2 expression, but the second case was negative. In contrast, the second case was positive for ER expression, whereas the first case was negative. Third, the second patient had two axillary lymph node metastases, whereas the first patient had none. We analysed the obtained data to derive the following conclusions: breast sebaceous carcinoma typically occurs in middle-aged women. Under the microscope, two types of cells can be observed in a solid nestlike or leafy distribution. One cell population consists of sebaceous gland-like tumour cells, which are mostly located in the centre of the lobules or cell nests. These represent a more differentiated cell type and are rich in vacuolar cytoplasm. The other cell population consists of smaller oval or fusiform non-vacuolar cells, mostly located at the periphery of the lobules or cell nests. These cells are usually undifferentiated and are thus difficult to distinguish from typical ductal carcinoma cells. Breast sebaceous carcinoma has a high rate of positive expression of ER, PR, p53, and EMA and a low rate of positive expression of HER-2 and GCDFP-15. Primary breast sebaceous cancer has the following diagnostic characteristics: sebaceous differentiation in at least $50 \%$ of cells in the absence of any evidence of originating in the cutaneous adnexa; features, such as ductal carcinoma differentiation, lobular carcinoma differentiation, and others, which can be found in primary breast sebaceous cancer, distinct from those in skin sebaceous adenocarcinoma; and a typical transitional structure between the cancer tissue and ductal epithelium. Breast sebaceous carcinoma should be distinguished from skin sebaceous adenocarcinoma, lipid-rich carcinoma, apocrine carcinoma, and glycogen-rich clear cell carcinoma, among others. Furthermore, this is a hormone receptor-dependent type of breast cancer that requires comprehensive treatment. Thus, after extensive analysis, we conclude that breast sebaceous carcinoma has low invasiveness and good prognosis.

Key words: sebaceous carcinoma of the breast, clinical, pathology. 


\section{Introduction}

Breast sebaceous adenocarcinoma is a rare and special type of invasive breast cancer, with as few as 21 cases reported at home and abroad. Among these cases, six have been reported in China (including the two cases described in this text). The World Health Organisation defines primary sebaceous carcinoma of the breast based on sebaceous differentiation in at least $50 \%$ of cells in the absence of any evidence of originating in the cutaneous adnexa [1]. The clinical pathology data and follow-up information of two breast sebaceous adenocarcinoma cases are discussed below with retrospective analysis of information on the clinical and pathological features, diagnosis, differential diagnosis, treatment and prognosis of breast sebaceous adenocarcinoma patients highlighted in studies at home and abroad.

\section{Clinical history}

\section{Case 1}

A 55-year-old female patient presented with an $8.0 \times 8.0 \mathrm{~cm}$ hard mass in the outer quadrant of her right breast. On October 18, 2016 the patient was diagnosed with invasive breast carcinoma based on biopsy results. The patient then received two cycles of neoadjuvant chemotherapy (epirubicin + cyclophosphamide) at Wuhan Union Hospital. Afterward, she came to Xiaogan City Centre Hospital for surgery. Prior to surgery, she underwent colour Doppler ultrasound scanning, which showed a mass with a mixed-echo pattern in the right breast (Fig. 1). Her CEA-125 level was $132.40 \mathrm{KU} / \mathrm{l}$, which was higher than the normal range (0-34.9 KU/1). Soon afterwards, she underwent modified radical mastectomy of the right breast. The tumour was approximately

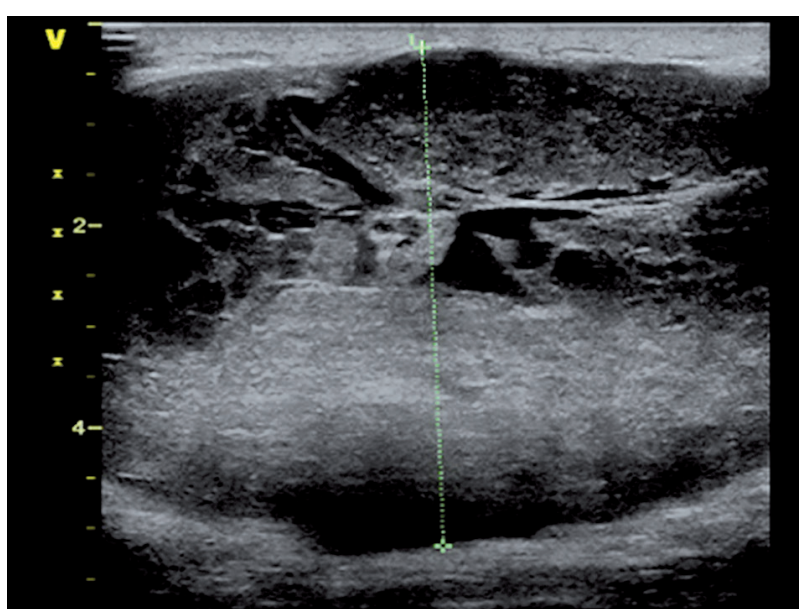

Fig. 1. Colour Doppler ultrasound image showing a mass of mixed echo pattern, with blurry and irregular border and a hypoechoic interior

$6.5 \times 6.5 \mathrm{~cm}$ in size. The tumour sections appeared grey in colour, with many irregular cysts inside. Under the microscope, we observed that the tumour cells were organised in a solid nest-like or leafy distribution and were composed of sebaceous gland cells and oval or fusiform cells (Fig. 2A). The sebaceous gland-like tumour cells were mostly located in the centre of the lobules or cellular nests. These represent a more differentiated cell type and are rich in vacuolar cytoplasm. The other cell population consisted of smaller oval or fusiform non-vacuolar cells, mostly located at the periphery of the lobules or cell nests. These cells are usually undifferentiated and are difficult to distinguish from typical ductal carcinoma cells. The sebaceous gland-like cells accounted for more than half of the total number of tumour cells. We also observed necrosis under the microscope (Fig. 3). The tumour was not connected with
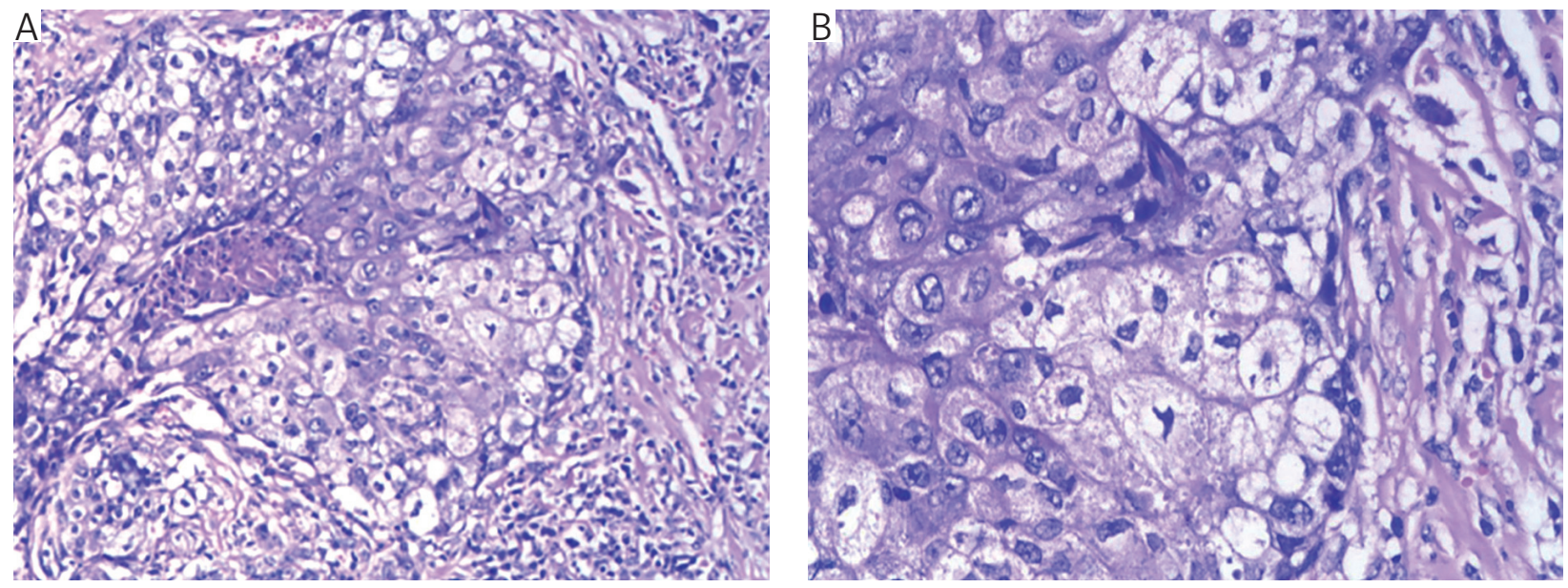

Fig. 2A, B. Two cell types: namely, sebaceous gland cells, which are rich in vacuolar cytoplasm and distributed in the centre of the leafy or nest-like structure, and smaller oval or fusiform cells distributed in the periphery $(\mathrm{HE}$ staining; $10 \times$ and $20 \times)$ 


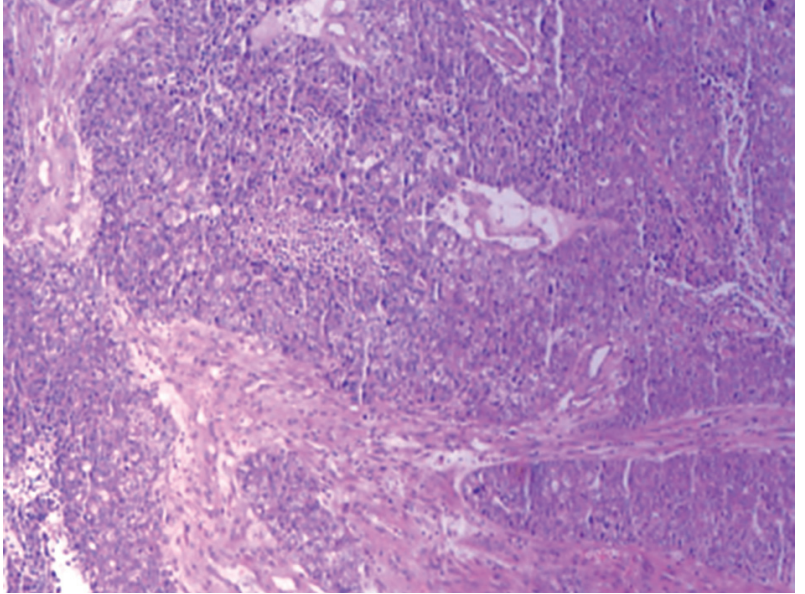

Fig. 3. Tumour cells arranged in solid nest-like or leafy distribution and a necrotic tumour interior; haematoxylin and eosin (HE) staining, $4 \times$

the skin, and there was no lymph node metastasis $(0 / 31)$. The immunohistochemistry results were as follows: ER (-), PR (-), Ki-67 (LI: +50\%), HER-2 $(3+)$ (Fig. 4), E-ca (+), GCDFP-15 (-), CK5/6 (partial + ), and CKH (partial + ). Subsequently, the patient received six cycles of chemotherapy (two cycles of epirubicin + cyclophosphamide and four cycles of docetaxel). The patient was diagnosed with HER-2-overexpressing breast cancer, for which targeted treatment is now available. However, she refused the treatment because of financial problems. Because of the large tumour size, the patient received radiotherapy. Until now, she has survived for 13 months without evidence of disease.

\section{Case 2}

A 42-year-old woman accidentally discovered a mass in her left breast. Colour doppler ultrasound scanning revealed a hypoechoic mass in the upper and lateral quadrant of the left breast. Mammograms showed a mass approximately $2.0 \times 1.5 \mathrm{~cm}$ in size in the upper and lateral quadrant of the left breast near the armpit (BI-RADS grade 4A) (Fig. 5). Biopsy showed a fibrous histiocytoma. CEA-125 tumour markers did not exhibit obvious abnormalities. The patient underwent tumour resection on the left breast under local anaesthesia on August 5, 2016. Postoperative pathological examination revealed the presence of invasive cancer. The patient subsequently underwent modified radical surgery of the left breast. The tissue section was white, and the tumour was approximately $2.5 \times 2.0 \mathrm{~cm}$ in size. Microscopic examination showed the presence the two types of cells similar to those described above with a nest-like or leafy distribution, and the sebaceous gland cells accounted for more than half of the total number of cells (Fig. 2B). The tumour was not associated with the skin. How-

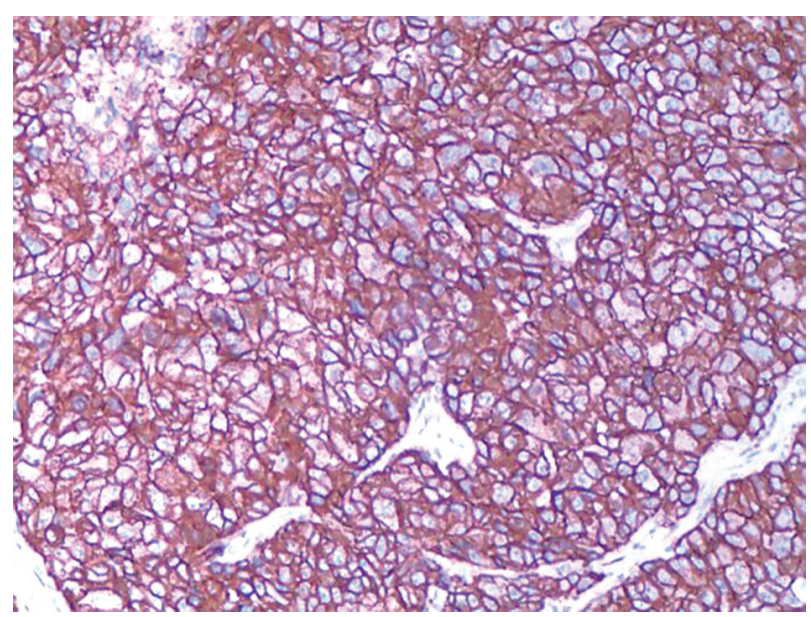

Fig. 4. Positive expression of HER-2 on tumour cells
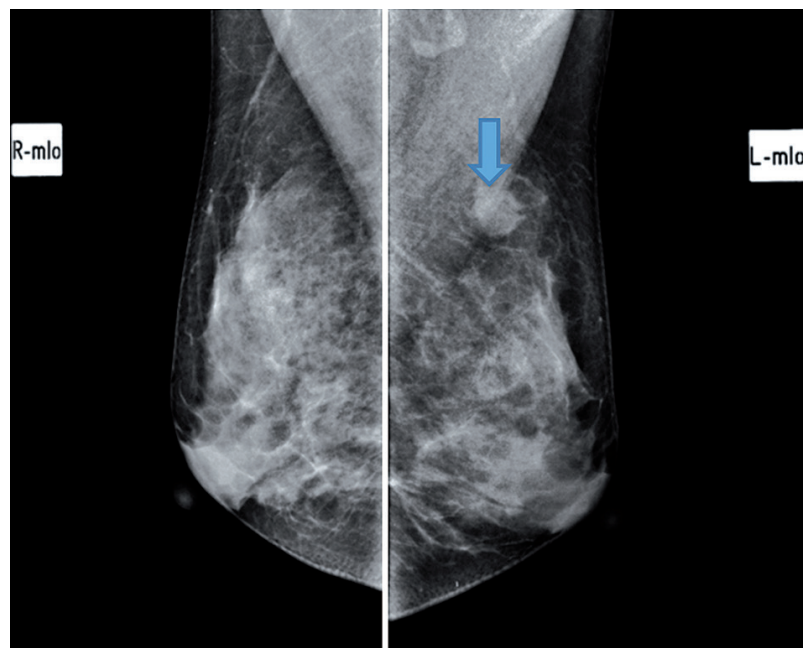

Fig. 5. Mammograms showing a mass of approximately $2.0 \times 1.5 \mathrm{~cm}$ in size in the upper and lateral quadrant of the left breast near the armpit (BI-RADS grade 4A)

ever, there were two axillary lymph node metastases. The immunohistochemistry results were as follows: ER $(+)$, PR $(-)$, HER-2 $(0)$, Ki-67 $(+60 \%)$, E-ca $(+)$, FAS $(+)$, FASL $(+)$, P53 (+), GCDFP-15 (-), CK5/6 (+), P63 (-), CD34 (-), SMA (-), and calponin (-). Subsequently, the patient received eight cycles of chemotherapy (four cycles of epirubicin +cyclophosphamide and four cycles of docetaxel), followed by radiotherapy and anti-hormone therapy (toremifene). Until now, she has survived for 15 months without evidence of disease.

\section{Material and methods}

First, we collected clinical pathology data and follow-up information from two cases of breast sebaceous adenocarcinoma in Xiaogan City Centre Hospital. Second, we gathered similar data and information from related studies published at home and 
Table I. Summary of clinicopathological features and follow-up information of patients with breast sebaceous adenocarcinoma

\begin{tabular}{|c|c|c|c|c|c|c|c|c|}
\hline Authors & YEAR & AGE & SEX & SIDE & $\begin{array}{l}\text { DiAMETER } \\
(\mathrm{CM})\end{array}$ & $\begin{array}{c}\text { LYMPH } \\
\text { NODE } \\
\text { METASTASIS } \\
\end{array}$ & Treatment & FOLLOW-UP \\
\hline $\begin{array}{l}\text { Van Bogaert } \\
\text { et al. [4] }\end{array}$ & 1977 & $33 \sim 76$ & & & $1.2 \sim 3.5$ & & & \\
\hline Prescott et al. [5] & 1992 & 74 & $\mathrm{~F}$ & $\mathrm{R}$ & & & & \\
\hline $\begin{array}{l}\text { Mazzella } \\
\text { et al. [6] }\end{array}$ & 1995 & 55 & $\mathrm{M}$ & $\mathrm{L}$ & 5 & + & & $\begin{array}{c}\text { ANOD } \\
10 \text { months }\end{array}$ \\
\hline $\begin{array}{l}\text { Tavassolli } \\
\text { et al. [7] }\end{array}$ & 1999 & 46 & $\mathrm{~F}$ & $\mathrm{R}$ & 7.5 & - & & \\
\hline Varga et al. [8] & 2000 & 45 & M & $\mathrm{R}$ & 2.5 & - & & $\begin{array}{c}\text { AWD } 132 \\
\text { months, skin } \\
\text { and bone MTS }\end{array}$ \\
\hline Hisaoka et al. [9] & 2006 & 71 & $\mathrm{~F}$ & $\mathrm{R}$ & 2 & + & & \\
\hline $\begin{array}{l}\text { Numoto } \\
\text { et al. }[10]\end{array}$ & 2007 & 49 & $\mathrm{~F}$ & $\mathrm{~L}$ & & & & \\
\hline $\begin{array}{l}\text { Moinfar } \\
\text { et al. }[11]\end{array}$ & 2007 & 75 & $\mathrm{~F}$ & $\mathrm{R}$ & & & & \\
\hline $\begin{array}{l}\text { Murakami } \\
\text { et al. }[12]\end{array}$ & 2009 & 50 & $\mathrm{~F}$ & $\mathrm{~L}$ & 2 & + & & $\begin{array}{c}\text { ANOD } \\
24 \text { months }\end{array}$ \\
\hline $\begin{array}{l}\text { Ramljak } \\
\text { et al. [13] }\end{array}$ & 2010 & 85 & $\mathrm{~F}$ & $\mathrm{~L}$ & 7.5 & & & \\
\hline \multirow[t]{4}{*}{ Svajdler et al. [2] } & 2015 & 65 & $\mathrm{~F}$ & $\mathrm{R}$ & 1.6 & + & $\begin{array}{c}\text { quadrantectomy } \\
\text { + SLN + axillary } \\
\text { dissection; ACT; RAT } \\
\text { (42.56 Gy); letrozole }\end{array}$ & $\begin{array}{l}\text { ANOD } \\
27 \text { months }\end{array}$ \\
\hline & & 61 & $\mathrm{~F}$ & $\mathrm{R}$ & 1.7 & + & $\begin{array}{c}\text { mastectomy }+ \\
\text { axillary dissection; } \\
\text { FAC; RAT }(50.0 \\
\text { Gy; paclitaxel + } \\
\text { bevacizumab + } \\
\text { bisphosphonates; } \\
\text { gemcitabine + } \\
\text { carboplatin }\end{array}$ & $\begin{array}{l}\text { MTS in the liver, } \\
\text { lungs and bone; } \\
\text { pathological } \\
\text { fracture } \\
\text { of the femur; } \\
\text { arrhythmia; } \\
\text { DOD } \\
28 \text { months }\end{array}$ \\
\hline & & 66 & $\mathrm{~F}$ & $\mathrm{R}$ & 3 & + & $\begin{array}{c}\text { mastectomy }+ \\
\text { axillary dissection; } \\
\text { FAC + tamoxifen; } \\
\text { RAT }(50.0 \mathrm{~Gy}) \\
\text { + vinorelbine } \\
\text { + capecitabine; } \\
\text { paclitaxel + } \\
\text { bevacizumab + } \\
\text { letrozole }\end{array}$ & $\begin{array}{l}\text { endometrial } \\
\text { carcinoma; local } \\
\text { recurrence; } \\
\text { mediastinal and } \\
\text { supraclavicular } \\
\text { lymph node } \\
\text { MTS; AWD } \\
70 \text { months }\end{array}$ \\
\hline & & 25 & $\mathrm{~F}$ & $\mathrm{R}$ & NA & - & $\begin{array}{c}\text { segmentectomy }+ \\
\text { axillary dissection; } \\
\text { AC + RAT (50.0 Gy) } \\
+ \text { HDR boost (15.0 Gy) } \\
+ \text { anti-oestrogen }\end{array}$ & $\begin{array}{l}\text { gave birth } \\
\text { to one child; } \\
\text { ANOD } \\
75 \text { months }\end{array}$ \\
\hline $\begin{array}{l}\text { Yamamoto } \\
\text { et al. [3] }\end{array}$ & 2015 & 80 & $\mathrm{~F}$ & $\mathrm{~L}$ & 3.5 & - & $\begin{array}{l}\text { partial mastectomy } \\
\text { and sentinel lymph } \\
\text { node biopsy }\end{array}$ & $\begin{array}{l}\text { ANOD } \\
16 \text { months }\end{array}$ \\
\hline $\begin{array}{l}\text { Zhang Junneng } \\
\text { et al. [14] }\end{array}$ & 2001 & 73 & M & $\mathrm{L}$ & 2.5 & + & $\begin{array}{c}\text { mastectomy }+ \\
\text { axillary dissection }\end{array}$ & $\begin{array}{l}\text { ANOD } \\
6 \text { months }\end{array}$ \\
\hline
\end{tabular}


Table I. Cont.

\begin{tabular}{|c|c|c|c|c|c|c|c|c|}
\hline Authors & YEAR & AgE & SEX & SIDE & $\begin{array}{l}\text { DIAMETER } \\
\quad(\mathrm{CM})\end{array}$ & $\begin{array}{c}\text { LYMPH } \\
\text { NODE } \\
\text { METASTASIS }\end{array}$ & Treatment & FOLLOW-UP \\
\hline $\begin{array}{l}\text { Chen Jian et } \\
\text { al. }[15]\end{array}$ & 2005 & 45 & $\mathrm{~F}$ & $\mathrm{~L}$ & 2.0 & & & \\
\hline $\begin{array}{l}\text { Qiu Zhenying et } \\
\text { al. }[16]\end{array}$ & 2016 & 62 & $\mathrm{~F}$ & $\mathrm{R}$ & 4.3 & - & $\begin{array}{l}\text { mastectomy }+ \\
\text { axillary dissection } \\
+ \text { four cycles } \\
\text { of chemotherapy }\end{array}$ & $\begin{array}{l}\text { ANOD } \\
6 \text { months }\end{array}$ \\
\hline $\begin{array}{l}\text { Zuo Zhong et } \\
\text { al. [17] }\end{array}$ & 2017 & 70 & $\mathrm{~F}$ & $\mathrm{~L}$ & 4.5 & + & & \\
\hline \multirow[t]{2}{*}{$\begin{array}{l}\text { Chen Heng et al. } \\
\text { (current case) }\end{array}$} & 2016 & 55 & $\mathrm{~F}$ & $\mathrm{R}$ & 6.5 & - & $\begin{array}{l}\text { neoadjuvant } \\
\text { chemotherapy } \\
\text { ( } 2 \text { cycles of } \mathrm{EC}) \\
\text { mastectomy }+ \\
\text { axillary dissection; } \\
\text { chemotherapy } \\
\text { (2 cycles of } \mathrm{EC}+ \\
4 \text { cycles of } \mathrm{T})\end{array}$ & $\begin{array}{l}\text { ANOD } \\
8 \text { months }\end{array}$ \\
\hline & 2016 & 42 & $\mathrm{~F}$ & $\mathrm{~L}$ & 2.5 & + & $\begin{array}{c}\text { mastectomy }+ \\
\text { axillary dissection; } \\
\text { chemotherapy } \\
(4 \text { cycles of EC + } \\
4 \text { cycles of T) }+ \text { RAT } \\
+ \text { anti-oestrogen } \\
\text { (toremifene) }\end{array}$ & $\begin{array}{l}\text { ANOD } \\
10 \text { months }\end{array}$ \\
\hline
\end{tabular}

abroad. Last, we retrospectively analysed the clinical and pathological features, diagnosis, differential diagnosis, treatment, and prognosis of patients with breast sebaceous adenocarcinoma.

\section{Results}

There are many similarities between the two cases, such as age, tumour location, treatment methods, and microscopic examination results, as described above. The differences between the two cases are as follows: First, their ultrasound performances were different. Pathology revealed the presence of irregular cysts in the first case, which was consistent with the ultrasound features, and microscopy revealed the presence of necrosis in the tumour. Second, their HER-2 expression and ER expression were different. Third, their lymph node metastasis patterns were not the same.

\section{Discussion}

Sebaceous gland cancer is rare. It often occurs in the eyelids and is accompanied by Muir-Torre syndrome, which is caused by mutations in DNA mis- match repair genes leading to the loss of expression of specific DNA mismatch repair proteins (MMRPs). Švajdler $e t$ al. reported four cases of breast sebaceous adenocarcinoma in the absence of visceral malignancies, but all the tumours retained the expression of DNA MMRPs. Therefore, the authors concluded that breast cancer with sebaceous gland characteristics are not associated with Muir-Torre syndrome [2], and our two cases did not have any visceral malignancy either, consistent with the conclusions of the previous study. Thus, as highlighted below, we analysed the data obtained thus far to derive several conclusions.

\section{Clinical and pathological features}

Breast sebaceous carcinoma typically occurs in middle-aged women, with a median age of 65 years. The breast mass is usually discovered accidentally by the patients or during regular physical examination. The clinical features of some breast sebaceous carcinoma tumours are very similar to those of breast fibroadenoma, and thus the tumours are sometimes removed as benign lesions such as in the case reported by Chen Jian et al. [15] and in patient 2 described herein. 
Table II. Summary of immunohistochemistry data for breast sebaceous adenocarcinoma

\begin{tabular}{|c|c|c|c|c|c|c|c|c|}
\hline Authors & ER & PR & HER-2 & $\mathrm{Ki}-67$ & P53 & GCDFP-15 & EMA & AR \\
\hline Prescott et al. [5] & & & & & & & + & \\
\hline Mazzella et al. [6] & + & + & & & & & & \\
\hline Tavassolli et al. [7] & - & + & & & & & & - \\
\hline Varga et al. [8] & + & + & - & & & & & \\
\hline Hisaoka et al. [9] & + & + & - & & & & + & - \\
\hline Numoto et al. $[10]$ & + & + & - & & & & + & \\
\hline Murakami et al. [12] & - & - & + & & & & + & + \\
\hline Ramljak et al. [13] & - & - & - & & & & & \\
\hline \multirow[t]{4}{*}{ Švajdler et al. [2] } & + & + & - & $30 \%$ & + & & + & \\
\hline & - & - & - & $80 \%$ & - & & + & \\
\hline & + & + & - & $5 \%$ & & - & - & \\
\hline & + & + & - & & & - & + & \\
\hline Yamamoto et al. [3] & - & - & - & & & & + & - \\
\hline Chen Jian et al. [15] & + & - & - & & & - & & \\
\hline Qiu Zhenying et al. [16] & + & + & - & $10 \%$ & & - & & \\
\hline Zuo Zhong et al. [17] & + & + & - & $35 \%$ & & & & \\
\hline \multirow{2}{*}{$\begin{array}{l}\text { Chen Heng et al. } \\
\text { (current case) }\end{array}$} & - & - & + & $50 \%$ & & - & & \\
\hline & + & - & - & $60 \%$ & + & - & & \\
\hline
\end{tabular}

In breast sebaceous carcinoma, two types of cells distributed in a solid nest-like and leafy pattern can be observed under the microscope. One cell population consists of sebaceous gland-like cancer cells, mostly located in the centre of the lobules or cell nests. These represent a more differentiated cell type and are rich in vacuolar cytoplasm. These cells have pleomorphic nuclei, which are often pushed to an eccentric position. The other cell population, which is mostly located at the periphery of the lobules or cell nests, consists of smaller oval or fusiform non-vacuolar cells with little cytoplasm. These cells are usually undifferentiated and are difficult to distinguish from typical ductal carcinoma cells. Generally, these cells are mixed with sebaceous gland-like cancer cells. Alternatively, these cells can also form individual clusters. The sebaceous gland-like cancer cells account for more than half of the total number of tumour cells. In breast sebaceous carcinoma, the tumour is typically not connected with the skin. Occasionally, features such as squamous epithelial differentiation, necrosis, lobular carcinoma in situ, and transition between the cancer tissue and ductal epithelium are also present. Furthermore, the incidence rate of lymph node metastasis in breast sebaceous carcinoma is $50 \%$, with 1-3 lymph node metastases.

The proportions of positivity for ER, PR, HER-2, p53, EMA, and GCDFP-15 are 64.71\%, 58.82\%, $13.33 \%, 66.67 \%, 88.89 \%$, and $0.00 \%$, respectively
(Tables I, II). Therefore, breast sebaceous carcinoma has a high rate of positive expression of ER, PR, p53, and EMA and a low rate of positive expression of HER-2 and GCDFP-15. The high positive rate of ER and PR expression in breast sebaceous adenocarcinoma indicates that this is a hormone receptor-dependent breast cancer, which is consistent with the view of Varga et al. [8]. Gao Renli et al. [18] concluded that the high expression of androgen receptor (AR) in breast cancer might indicate a low invasive potential and good prognosis. Until now, the only patient diagnosed with breast sebaceous carcinoma with a positive expression of AR has survived for 24 months without evidence of disease, which supports the notion mentioned above. Fasanella et al. [19] reported that the proportion of $\mathrm{Ki}-67$-positive cells in breast carcinoma is approximately $36 \pm 14 \%$, which is consistent with our data $(36.57 \%)$. Based on the hormone receptor status and HER-2 expression status, the number of breast sebaceous cancer cases of the luminal, HER-2-positive, and triple-negative subtype are 9, 3, and 2, respectively, indicating that the luminal type is the more common subtype of breast sebaceous adenocarcinoma.

\section{Diagnosis}

Here, we summarise some aspects for the diagnosis of primary breast sebaceous adenocarcinoma according to the views of a number of scholars. Primary 
breast sebaceous adenocarcinoma is defined based on sebaceous differentiation in at least $50 \%$ of cells in the absence of any evidence of originating in the cutaneous adnexa. Moreover, the tumours have features, such as ductal carcinoma differentiation, lobular carcinoma differentiation, and others, that can be found in primary breast sebaceous cancer distinct from those in skin sebaceous adenocarcinoma. Additionally, a typical transitional structure can be found between the cancer tissue and the ductal epithelium in primary breast sebaceous adenocarcinoma.

\section{Differential diagnosis}

Breast sebaceous adenocarcinoma should be distinguished from cancers such as skin sebaceous adenocarcinoma, lipid-rich carcinoma, apocrine carcinoma, and glycogen-rich clear cell carcinoma. The features for differential diagnoses are described below.

The differences between breast sebaceous adenocarcinoma and skin sebaceous adenocarcinoma are as follows: First, in the case of breast sebaceous adenocarcinoma, the tumour is located in the breast, and there is no evidence of origin from the cutaneous adnexa. Second, the tumours have features, such as ductal carcinoma differentiation, lobular carcinoma differentiation and others, which can be found in primary breast sebaceous cancer distinct from those in skin sebaceous adenocarcinoma. Last, even when the tumour is connected to the skin, if a typical transitional structure is observed between the cancer tissue and breast ductal epithelium, a diagnosis of breast sebaceous adenocarcinoma can be made.

The differences between breast sebaceous adenocarcinoma and lipid-rich carcinoma are as follows: First, $90 \%$ of lipid-rich carcinoma cells contain varying levels of intracellular lipids. Second, lipid-rich carcinoma consists of more than two types of cells, and there are no undifferentiated cells or cells with squamous epithelial differentiation. Third, in lipid-rich carcinoma, the cells have a cord-like and irregular distribution but not solid nest-like or leafy distribution such as that observed in breast sebaceous adenocarcinoma.

The differences between breast sebaceous adenocarcinoma and apocrine carcinoma are as follows: First, apocrine carcinoma consists of two kinds of cells, which both have large nuclei and obvious nucleoli. These cells include eosinophilic or granulocyte-like cells with abundant cytoplasm and vacuole-like cells. There are no small oval or fusiform non-vacuolar cells or cells with squamous epithelial differentiation. Second, the cells have glandular and tubular distribution and not solid nest-like or leafy distribution such as that observed in breast sebaceous adenocarcinoma. Additionally, apocrine carcinoma is associated with apocrine secretion on the cavity surface. Third, GCDFP-15 expression is positive in both cell types in apocrine carcinoma, whereas GCDFP-15 expression is negative in the cells of breast sebaceous adenocarcinoma.

The differences between breast sebaceous adenocarcinoma and glycogen-rich clear cell carcinoma are as follows: The cells in glycogen-rich clear cell carcinoma have abundant cytoplasm rich in glycogen. These cells are also positive for periodic acid-Schiff (PAS) staining. Moreover, glycogen-rich clear cell carcinoma lacks vacuole-like features, two cell types, and lobular structures.

\section{Prognosis}

There are a total of 12 cases of breast sebaceous adenocarcinoma with follow-up data. Nine cases have no signs of recurrence. The other three cases had metastasis or breast cancer recurrence at 132 months, 18 months, and 26 months; among these three patients, one died from arrhythmia during surgery. The clinical features of some breast sebaceous carcinoma tumours are very similar to those of breast fibroadenoma, and thus, the tumours are sometimes removed as benign lesions, and patients often need a second surgery. Regarding the pathological aspect, the World Health Organisation defines primary breast sebaceous carcinoma based on sebaceous differentiation in at least $50 \%$ of cells, indicating that most of the tumour cells are differentiated. Furthermore, the incidence rate of lymph node metastasis in patients with breast sebaceous carcinoma is $50 \%$, with $1-3$ lymph node metastases. Additionally, the average proportion of cells positive for $\mathrm{Ki}-67$, which is a tumour proliferation index, is consistent with our findings. Moreover, most breast sebaceous carcinoma belong to the luminal subtype, which has a good prognosis. After a comprehensive analysis of these data, we conclude that breast sebaceous carcinoma has low invasiveness and good prognosis.

\section{Conclusions}

Breast sebaceous carcinoma typically occurs in middle-aged women. Under the microscope, two types of cells can be observed in these tumours in a solid nest-like or leafy distribution. One cell population consists of sebaceous gland-like tumour cells, which are mostly located in the centre of the lobules or cellular nests. These represent a more differentiated cell type and are rich in vacuolar cytoplasm. The other cell population consists of smaller oval or fusiform non-vacuolar cells, mostly located at the periphery of the lobules or cell nests. These cells are usually undifferentiated and are difficult to distinguish from typical ductal carcinoma cells. Additionally, breast sebaceous carcinoma has a high rate of positive expression of ER, PR, p53, and EMA and a low rate of positive expression of HER-2 and 
GCDFP-15. Primary breast sebaceous carcinoma has the following diagnostic characteristics: sebaceous differentiation in at least $50 \%$ of cells in the absence of any evidence of originating in the cutaneous adnexa; features, such as ductal carcinoma differentiation, lobular carcinoma differentiation and others, that can be found in primary breast sebaceous cancer distinct from those in skin sebaceous adenocarcinoma; and a typical transitional structure between the cancer tissue and ductal epithelium. Nevertheless, breast sebaceous carcinoma should be distinguished from skin sebaceous adenocarcinoma, lipid-rich carcinoma, apocrine carcinoma, and glycogen-rich clear cell carcinoma, among others. Furthermore, this is a hormone receptor-dependent type of breast cancer, which requires comprehensive treatment. Therefore, after extensive analysis of the data, we conclude that breast sebaceous carcinoma has low invasiveness and good prognosis.

\section{The authors declare no conflict of interest.}

\section{References}

1. Eusebi V, Ichihara S, Vincent-Salomon A, et al. Exceptionally rare types and variants. Lakhani SR, Ellis IO, Schnitt SJ (eds.). WHO classification of tumours of the breast. 4th ed. IARC, Lyon 2012; 71-76.

2. Švajdler M, Baník P, Poliaková K, et al. Sebaceous carcinoma of the breast: report of four cases and review of the literature. Pol J Pathol 2015; 66: 142-148.

3. Yamamoto Y, Nakamura T, Koyama H, et al. Sebaceous carcinoma of the breast: a case report. Surg Case Rep 2017; 3: 38.

4. van Bogaert LJ, Maldague P. Histologic variants of lipidsecreting carcinoma of the breast. Virchows Arch A Pathol Anat Histol 1977; 375: 345-353.

5. Prescott RJ, Eyden BP, Reeve NL. Sebaceous differentiation in a breast carcinoma with ductal, myoepithelial and squamous elements. Histopathology 1992; 21: 181-184.

6. Mazzella FM, Sieber SC, Braza F. Ductal carcinoma of male breast with prominent lipid-rich component. Pathology 1995 27: 280-283.

7. Tavassoli FA. Sebaceous carcinoma. In: Pathology of the breast. Medina MP, Greenfield S (eds.). 2nd ed. Appleton and Lange, Stamford 1999; 555-558.

8. Varga Z, Kolb SA, Flury R, et al. Sebaceous carcinoma of the breast. Pathol Int 2000; 50: 63-66.

9. Hisaoka M, Takamatsu Y, Hirano Y, et al. Sebaceous carcinoma of the breast: case report and review of the literature. Virchows Arch 2006; 449: 484-488.

10. Numoto S, Iwata J, Nakai T, Aki F. A case of sebaceous carcinoma of the breast. Jpn J Diagn Pathol 2007; 24: 58-61.

11. Moinfar F. Essentials of diagnostic breast pathology. A practical approach. Springer-Verlag, Berlin Heidelberg 2007; 232.

12. Murakami A, Kawachi K, Sasaki T, et al. Sebaceous carcinoma of the breast. Pathol Int 2009; 59: 188-192.

13. Ramljak V, Sarcevic, B, Vrdoljak DV, et al. Fine needle aspiration cytology in diagnosing rare breast carcinoma - two case reports. Coll Antropol 2010; 34: 201-205.

14. Zhang JN. A case of sebaceous carcinoma of the breast. Zhong Liu Yan Jiu Yu Lin Chuang 2001; 13: 312
15. Chen J, Guo RF, Liang HY, et al. Clinicopathological diagnosis of sebaceous gland-like carcinoma of breast. Lin Chuang Yu Shi Yan Bing Li Xue Za Zhi 2005; 20: 273-276.

16. Qiu ZY, Zhang LY, Wei JG, et al. A case of sebaceous carcinoma of the breast. Lin Chuang Yu Shi Yan Bing Li Xue Za Zhi 2016; 32: 599-600.

17. Zuo Z, Feng L, Wang C. Breast primary sebaceous adenocarcinoma: a case report and literature review. Lin Chuang Yu Shi Yan Bing Li Xue Za Zhi 2017; 33: 453-455.

18. Gao RL, Zhang D, Ye HY, et al. Expression of androgen receptor(AR) in breast carcinoma and its clinical pathological significance. Xian Dai Zhong Liu Yi Xue 2013; 21: 1257-1259.

19. Fasanella S, Leonardi E, Cantaloni C, et al. Proliferative activity in human breast cancer: Ki-67 automated evaluation and the influence of different Ki-67 equivalent antibodies. Diagn Pathol 2011; 6 Suppl 1: S7.

\section{Address for correspondence}

Tan Wei

Wuhan University of Science and Technology

No.2, Huangjiahu West Road

Hongshan District

457 Wuhan, China 